\title{
OBSERVATIONS OF A NEW COLORATION IN Philautus hoffmanni MEEGASKUMBURA \& MANAMENDRA-ARACHCHI, 2005 (AMPHIBIA: RHACOPHORIDAE) FROM DUMBARA HIGHLANDS
}

A. A. Thasun Amarasinghe ${ }^{1,2}$, W. A. A. D. Gayan Pradeep ${ }^{1}$ and D. M. S. Suranjan Karunarathna ${ }^{3}$

${ }^{1}$ Taprobanica Nature Conservation Society, 146, Kendalanda, Homagama, Sri Lanka

${ }^{3}$ IUCN - Sri Lanka Country office, No. 53, Horton place, Colombo 07, Sri Lanka

Corresponding author: ${ }^{2}$ aathasun@gmail.com

\begin{abstract}
Philautus hoffmanni is considered the sister species of $P$. asankai. According to published literature the dorsal color of $P$. hoffmanni is usually pale green with reddish brown, ash and brown spots. White coloration in these frogs has not been reported previously even $P$. asankai shows ashy white. This white coloration of $P$. hoffmanni highlights again the close relation of this species with $P$. asankai. This is the second known case of white body coloration in this genus. This coloration is related to nycthemeral cycle, the same specimen being whitish at day, and pale green or brown at night.
\end{abstract}

Key words: Philautus asankai, color change, nycthemeral cycle, Sri Lanka

\section{Introduction}

The island of Sri Lanka harbours 65 species of the Rhacophorid genus Philautus (ManamendraArachchi \& Pethiyagoda 2005, 2006; Meegaskumbura \& Manamendra-Arachchi 2005; Meegaskumbura et al. 2007; Meegaskumbura et al. 2009; Pethiyagoda et al. 2006), that includes Philautus asankai Manamendra-Arachchi \& Pethiyagoda 2005 and Philautus hoffmanni Meegaskumbura \& Manamendra-Arachchi 2005, this two sister species that inhabit two adjacent moist mountain ranges (Manamendra-Arachchi \& Pethiyagoda 2006; Meegaskumbura \& Manamendra-Arachchi 2005). $P$. asankai is restricted to the Central hills, at elevations between 810 and $1830 \mathrm{~m}$. Its dorsal color is very variable: e.g., pale green, pale brown with ashy spots, light bluish (Manamendra-Arachchi \& Pethiyagoda 2005) or ashy white (see fig. 116 in ManamendraArachchi \& Pethiyagoda 2005). During the daytime, these frogs generally assume a lighter 
coloration and at night darker colorations, such as green and brown (pers. comm. Kelum Manamendra-Arachchi 21 May 2009).

Above mentioned two sister species are separated from each other by a $12 \mathrm{~S}$ and $16 \mathrm{~S}$ sequence divergence of $1.01 \%$ and a cytochrome-b divergence of $6.04 \%$ (see table 1 \& 2 in Meegaskumbura \& Manamendra-Arachchi 2005). $P$. hoffmanni is distinguished from all other Sri Lankan congeners by a combination of the following characters: mature males 21.2-23.4 mm SVL; tympanum present, distinct; snout angle category 6 or 7 (Meegaskumbura \& ManamendraArachchi 2005); snout rounded in lateral aspect; interorbital space flat; fine, horn-like spinules absent on lower flank; canthal edges rounded; vomerine ridge and lingual papilla absent; nuptial pads absent in males (Meegaskumbura \& Manamendra-Arachchi 2005).

According to the published literature and our observations, the dorsal color of $P$. hoffmanni is usually pale green in the morning with reddish brown, ash and brown spots (see fig. 10a \& b in Meegaskumbura \& Manamendra-Arachchi 2005). White coloration in these frogs has not been reported previously. Meegaskumbura \& Manamendra-Arachchi (2005) described the coloration of this species as follows: loreal region brown, both upper and lower lips ash; limbs dorsally ashy brown; digits dorsally bright yellow and ash; flank ash; inguinal zone, posterior and anterior thigh ash with golden-yellow dots; ventral aspect of digits, limbs and body golden yellow. This species has been only known until now from Cobett's Gap (alt. 1,245 m) in the southern parts of the Knuckles moist massif (Meegaskumbura \& Manamendra-Arachchi 2005).

Here we describe a new coloration of Philautus hoffmanni observed in a new location in the northern parts of the Knuckles hills.

\section{Results}

Male, $22.6 \mathrm{~mm}$ SVL. Location: Riverston Estate, on road from Matale to Pallegama, Dumbara [Knuckles], elevation $1,435 \mathrm{~m} \quad\left(7^{\circ} 24^{\prime} 54.74\right.$ 'N, 8048'34.76”E). Date: 15 March 2008. This specimen was not preserved after photography and released soon after recording data at the original location. Color in life (fig. 1): Dorsally ashy white with sky blue spots. loreal region sky blue, both upper and lower lips ashy white. Canthal edges bright yellow from the snout to mid supra ocular (In
P. asankai this yellow band is indistinct). Limbs dorsally ashy white. Digits dorsally bright yellow. Flank brownish ash. Inguinal zone, posterior and anterior thigh yellow with golden-brown dots. Ventral aspect of digits, limbs and body golden yellow.

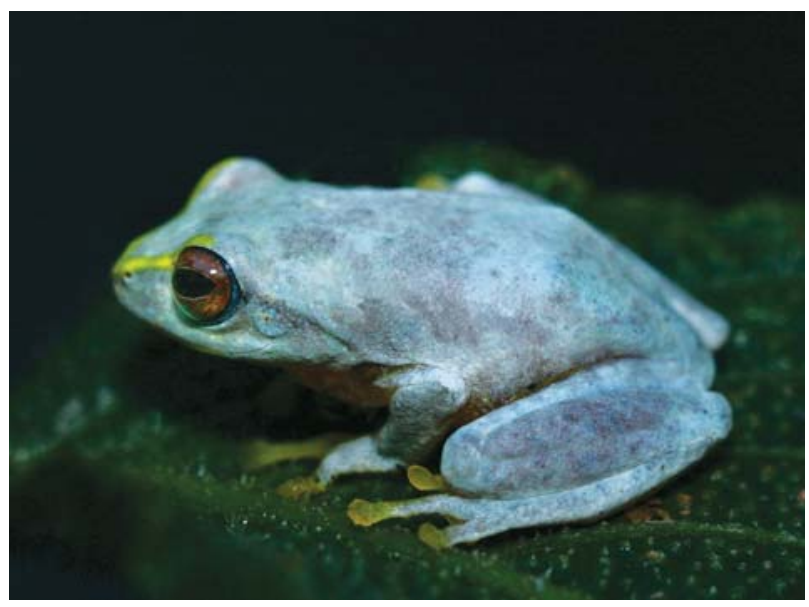

Fig. 01: White coloration of P. hoffmanni

\section{Discussion}

This white coloration of $P$. hoffmanni highlights again the close relationship of this species with $P$. asankai. This is the second known white body coloration in Sri Lankan Philautus. This coloration is related to nycthemeral cycle, the same specimen being whitish at day, and pale green or brown at night. Also the same individual was observed in different conditions of environment. Within few minutes after capturing it changed it body color in to brown. After releasing in to a plant it changed its body color to green within few minutes and then changed to white after a few more minutes. However we observed a few white colored $P$. hoffmanni males while they were calling.

In addition to this the same individuals of $P$. asankai were observed in the day and at night. The observations were the same as for $P$. hoffmanni and again observed a few bright white colored calling males. This species categorized as Endangered (IUCNSL \& MENR, 2007).

Philautus hoffmanni is restricted to the Knuckles hills. It might also occur in other cloud forest areas of these hills (Meegaskumbura \& ManamendraArachchi 2005). This record is the first from Riverstorn (described here), in Thangappuwa and Deanston areas. These frogs were observed on Strobilanthes sp. bushes; and in this type of habitat their color is light green. These shrubs are found in gaps within closed canopy cloud forest and forest edges, and in the cardamom plantations in these 
areas. Meegaskumbura \& Manamendra-Arachchi (2005) observed P. hoffmanni only in close proximity to relatively undisturbed montane forests, but we recorded it also in disturbed anthropogenic habitats with developed undergrowth and close to montane forests.

\section{Acknowledgements}

We would like to express our sincere thank to Madhava Meegaskumbura (Harvard University, USA) and Kelum Manamendra-Arachchi (WHT) for reviewing the manuscript and also wish to thank Sudath Nanayakkara (WHT) for providing valuable comments. Finally we are grateful to Vimukthi Weeratunge (IUCN Sri Lanka) for providing photographs in life.

\section{Literature Cited}

IUCNSL and MENR 2007. The 2007 Red List of Threatened Fauna and Flora of Sri Lanka. IUCN Sri Lanka, Colombo: 148.

Manamendra-Arachchi, K. and R. Pethiyagoda. 2005. The Sri Lankan shrub-frogs of the genus Philautus Gistel, 1848 (Ranidae: Rhacophorinae) with description of 27 new species. The Raffles Bulletin of Zoology, Supplement No, 12: 163-303.

Manamendra-Arachchi, K. and R. Pethiyagoda. 2006. Sri Lankawe Ubhayajeeveen "Amphibian Fauna of Sri Lanka" (text in Sinhala). Wildlife Heritage Trust of Sri Lanka: 440.

Meegaskumbura, M. and K. Manamendra-Arachchi. 2005. Description of eight new species of shrub-frogs (Ranidae: Rhacophorinae: Philautus) from Sri Lanka. The Raffles Bulletin of Zoology, Supplement No, 12: 305-338.

Meegaskumbura, M., K. Manamendra-Arachchi, C. J. Schneider and R. Pethiyagoda. 2007. New species amongst Sri Lanka's extinct shrub frogs (Amphibia: Rhacophoridae: Philautus). Zootaxa, 1397: 1-15.

Meegaskumbura, M., K. Manamendra-Arachchi and R. Pethiyagoda. 2009. Two new species of shrub frogs (Rhacophoridae: Philautus) from the lowlands of Sri Lanka. Zootaxa, 2122: 51-68.

Pethiyagoda R., K. Manamendra-Arachchi, M.M. Bahir and M. Meegaskumbura. 2006. Sri Lanka amphibians: diversity, uniqueness and conservation. 125-133. In: Fauna of Sri Lanka. Status of Taxonomy, Research and Conservation. C. N. B. Bambaradeniya (Ed.). The World Conservation Union, Colombo, Sri Lanka and Government of Sri Lanka. 